\title{
Issues and Challenges of Education for Disabilities (Blind) in Muslim Community in Malaysia by using Braille ${ }^{1}$
}

\author{
Ahmad Yunus Mohd Noor ${ }^{1, a^{*}}$ and Wan Kamal Mujani ${ }^{2, b}$ \\ 1, 2 Universiti Kebangsaan Malaysia \\ ayunus@ukm.edu.mycorresponding author, binawan@ukm.edu.my
}

Keywords: Learning Disabilities; Malaysia; Braille; Issues; challenges

\begin{abstract}
The production of Braille code is important to people with learning disabilities especially those who have sight problem. This article attempts to find out the issues and challenges of learning disabilities experienced by members of the association PERTIS using Braille approach. The study also aims to identify the level of knowledge, understanding and practice of the use of Braille among the members of the association. This study undertakes an analysis of people with learning disabilities based on issues and challenges as the main sources of reference by adopting the document analysis method. The outcome of this article suggests that the Malaysia government needs to make improvements in order to enhance the quality of education for people with learning disabilities and create a special education program for them. Besides that the methods and point solutions to the problems faced by this kind of people is considered as a new issue and supposed to be handled by government and private sector.
\end{abstract}

\section{Introduction}

Referring to the Ministry of Health Malaysia, learning disabilities is considered as common problem among $10 \%-15 \%$ of the pupils which can be classified as general or specific disability. Various terms are used worldwide to describe Learning Disability that include; intellectual disabilities, Down syndrome (U.S) or learning difficulties (U.K). The National Joint Committee on Learning Disabilities (NJCLD) [1990] describes that the learning disabilities can be referred to a heterogeneous group of disorders manifested by significant difficulties in the acquisition and use of listening, speaking, reading, writing, reasoning, or mathematical abilities. [J. Taymans et. al 2009]. Indeed, problems in self-regulatory behaviors, social perception, and social interaction may exist with learning disabilities but do not by themselves who constitute a learning disability. Although learning disabilities may occur concomitantly with other handicapping conditions (for example, sensory impairment, mental retardation, serious emotional disturbance), or with extrinsic influences (such as cultural differences, insufficient or inappropriate instruction), they are not the result of those conditions or influences. According to Berdine, WH and Blackhurst, AE. [1985], disabilities is referred to the difficulties encountered by individuals to interact with the surrounding. Disabled means the dysfunction or loss of a certain body parts or organs while imperfection means body tissues injury or flaw. Upon all, it is significant to highlight that all the terms used are not absolute and yet still being debate locally and internationally.

Locally, Department of Social Welfare of Malaysia defines disabled as individuals who was unable to attain parts or entirely the general basic needs or lack of social assimilation due to a certain disability either physically or mentally since they were born or due to some condition [S. Sanmargaraja, S. Wee 2008]. However the researcher tends to emphasize on the issues and challenges of blindness disability among the Muslim community in Malaysia. Barely, they are unable to use their sense of sight properly in overcoming the encountered learning difficulties. Thus, the use of Braille code is a perfect solution to help them in order to overcome learning problems.

\footnotetext{
${ }^{1}$ This research was financially supported by the Fundamental Research Grant Scheme from Malaysian Ministry of Education [Grant NO.: FRGS/1/2014/SSI03/UKM/02/5].
} 


\section{Issues and Challenges}

In general, "Persons with Disabilities Act 2002" constitutes a special law for the disabled in Malaysia to be protected and defended. Constitutionally, the disabled can claim his rights under Article 8 of the Federal Constitution which guarantees equality to everyone but the real situation is allowed by the constitution. The Act also includes any discrimination against a person solely on the ground of disability in employment, education, housing, transportation, undertaking business, sports, recreational activities, access to public places, access to public facilities and services [Kamarulzaman Kamaruddin 2007]. Finally, it refers to the inability of any kind of barriers that exist so deprived, potential, potential contributions and participation of individuals or group of individuals in a community or country. Based on the development of Disability Studies (Disability Studies), there exists a variety of model or framework that defines the term "incapacity" of the Medical Model (Medical Model) until Biopsychosocial Model (biopsychosocial model). Nadir Nasir [2 August 2015] Sinar Harian Newspaper.

Norhasnira et. al [2013] explains that education is facing a range of development and change more challenging and complex. New demands such as the impact of globalization, innovation and education is one of the global knowledge flows and trends that are important in shaping the development of learning. In meeting the urgent needs of the Ministry of Education also plays a role in helping these people to not drop out of school in Malaysia. Persons with Disabilities Act was passed in Parliament (Senate) on 24 December 2007 and was gazetted on 24 January 2008 and came into force on 7 July 2008. The PWD Act provides for the recognition of the rights of persons with disabilities and to change the concept of the welfare of the disabled from the right-based concept. The Act also allows the disabled have the right to equalization of opportunities and full participation in society on par with other community members. Handicapped Act also provides for matters related to registration, protection, rehabilitation, development and well-being of people with disabilities.

Therefore, the Government of Malaysia does not release hand to provide relevant and quality education to the less fortunate. The government's policy that "education for this group should be formed an important part of the National Education Planning, curriculum development and school organization" [Disabled Persons Act 2002]. Therefore, it is unlawful for any education authority to discriminate against disabled people by refusing or failing to accept that person's application for admission as a student. Education authorities also do not discriminate against a student on the grounds of disability by denying or limiting their access to the relevant authorities to any benefits provided by the education authorities; to expel the student or student lead to such accidents.

Special education programs are implemented to visually impaired people in the country are part of the National Education Association, because it is not immune from the typical student involved with this curriculum. This means that the rights and opportunities for visually impaired people to participate in the formal education system in Malaysia is not negligible [Wong 2005]. In 1962 and subsequent years Ministry of Education has organized an integrated plan for providing special education for deaf students in regular schools, followed by students with visual impairment. In 1964 a special unit known as the Special Education Unit was established in the School Division to uphold the special education for the disabled. According Murshid Ahmad [1974], education in the view of Islam must be able to produce human stance and a strong belief in the ideals of Islam [Abdul Rahman \& Zakaria 2001] and can compensate him between the demands of both worlds [Ghazali 1982].

Further, the issues that exist in learning disability issues for the blind comprises several aspects. Among the aspects academically and professionally qualified teachers, knowledge about the characteristics of the special needs of the visually impaired and the ability and confidence of teachers in delivering education to visually impaired people with special needs [Mohd Mokhtar \& Aliza 2004] and supports the need for infrastructure to teaching and learning [Mohd Hanafi et. al 2009]. According to Norakyairee Mohd Raus et. al [2013] problems encountered by teachers when they have not mastered Braille code Qur'an. Results of interviews said they did not have immediate basis to read the Qur'an uses the Koran in Braille at the outset to be a teacher because she was not 
exposed during teacher training. In fact, through interviews also showed that three teachers did not teach the Qur'an uses the Qur'an in Braille.

Aspects of teaching practice has been widely discussed by scholars in education to shape a culture of teaching and learning in the education system [Ahmad Yunus \& Ab. Halim, 2010]. In the context of these problems, teachers need to learn to explore the science of deep and update knowledge to be more advanced than the students. Increased knowledge and experience is essential to make teaching more effective especially in terms of teaching and learning ( $\mathrm{P} \& \mathrm{P}$ ) for people with special needs in the current National Special Education [Norhasnira Ibrahim et. al 2013], particularly among members PERTIS. According to JW Wood [2002], teaching for people with special needs should have the skills to teach the needs of learning disabled category. For disabled people blind, they use Braille machines for writing and reading and learning materials in Braille code, including the Qur'an and Hadith in Braille. Therefore, teaching people with special needs should have the skills to use Braille machines Braille writing and reading, especially Koran Braille [Mohd Mokhtar \& Aliza 2004] to facilitate learning among members of the association PERTIS.

The next challenge is the issue of teachers faced a problem of teach members of the association PERTIS who do not have immediate basic learning, such as recognizing letters hija'iyyah for learning the Qur'an and alphabetical character. This leads to time constraints when teachers have to teach one by one. Hajarul Bahti et. al [2010] explains, in a very limited time constraints, the teacher certainly cannot give special attention to improving the reading skills of students and using Braille students one by one. Based on the observation of the constraints, the main constraints that must be addressed is the appropriate level of knowledge regarding the teaching Braille code. Letters and symbols in Braille reading material consists of numerical tations and six raised dots arranged in two columns and three rows [L. Pring 1994]. Braille and print is not the same orthography and understanding the internal features Braille code is very important for the teaching [Hamp \& Caton 1984]. However, there are different rates of speed reading Braille; some readers rather quickly, with an average of about half the speed of vision, can speak 150 words in a minute, but many who read slower than the speed of under 40 words per minute. Often write using Braille was introduced at almost the same with reading.

\section{Conclusion}

Thus, a writing machine called the Perkins Brailler enables users to produce Braille. Class reading is important and can be the difference for the child to achieve success and failure [Harley, Truan, \& Sanford, 1987]. For example, children who are blind may not be able to do the job with the same enthusiasm as a child who can see. Therefore, it is important to pay attention as one of the motivating factors for them [Spungin, 1989]. Spungin underscores the fact that failure to use the Braille usually not caused by a number of difficulties inherent in the project, but more focused on more practical considerations. When the "Whole World" for teaching reading has been popular, the rules in Braille was introduced at the beginning of reading instruction. The use of Braille code has been used in teaching special education system in Malaysia to assist and facilitate the process of learning them. So, Norhasnira Ibrahim et. al [2013] explain, to understand literature in Braille writing, we must first learn and understand the codes that Braille is no confusion in the code. In addition, the Braille code also serves as a guideline for normal classes that allow them to teach, educate and understand what it is to be conveyed to the visually impaired this.

Therefore, the exploration of the issues and challenges faced by the members of the association PERTIS to the problem of learning disabilities is to find common solutions and appropriate methods to address them. It aims to help the authorities to cope as well as making improvements especially in building the quality of education in the State Special Education program. In fact, the methods and point solutions to the problems faced by this group are not an issue that unable to be handled by those involved. 


\section{References}

[1]. Ahmad Yunus Mohd Noor. (2015). Hadis Bertulisan Braille dalam Transformasi Pendidikan Khas.

[2]. E.P, Hamp \& H, Caton. (1984). A Fresh Look at The Sign System of The Braille Code. Journal of Visual Impairment and Blindness,78(5), 210-214.

[3]. Hajarul Bahti Zakaria, Mohd Huzairi Awang @ Husain, Bani Hidayat Mohd Shafie. (2010). Isu dan Cabaran Guru dalam Pendidikan al-Qur'an Pelajar Bermasalah Penglihatan. Proceeding of The 4th International Conference on Teacher Education; Join Conference UPI \& UPSI Bandung, Indonesia, 8-10 November 2010.

[4]. Kamarulzaman Kamaruddin. (2007). Adult Learning for People with Disabilities in Malaysia: Provisions and Services. The Journal of Human Resource and Adult Learning. Vol 3, Num 2, December 2007.

[5]. L, Pring. (1994). Touch and Go: Learning to Read Braille. Reading Research Quarterly, Vol. 29, No. 1 (Jan. - Feb. - Mar., 1994), pp. 66-74 Published by: Wiley On Behalf of The International Reading Association.

[6]. Mohd Hanafi Mohd Yasin, Noraini Mohd Salleh, Hasnah Toran \& Mohd Mokhtar Tahar. (2009). Infrastruktur Bilik Darjah Program Integrasi Pendidikan Khas Menyokong Pengajaran dan Pembelajaran Pendidikan Islam. Wacana Pendidikan Islam Siri Ke-7 (Peringkat Nusantara) (pp. 540-546). Gontor: Institusi Studi Islam Darussalam, Indonesia.

[7]. Mohd Mokhtar Tahar \& Aliza Alias. (2004). Isu Pengajaran dan Pembelajaran Pendidikan Islam Pelajar Berkeperluan Khas. Wacana Pendidikan Islam (siri 3) (pp. 395-406). Bangi: Fakulti Pendidikan Universiti Kebangsaan Malaysia.

[8]. Norhasnira Ibrahim, Norakyairee Mohd Raus, Nur Adzam Rasdi, Noornajihan Jaafar, Norazman Alias, Norullisza Khosim \& Norzulaili Mohd Ghazali. (2013). Modul pengajaran alQuran Braille: Tinjauan Awal. Tajdid In Qur’anic Studies. Universiti Sains Islam Malaysia.

[9]. R.K, Harley, M.B, Truan, \& L.D, Sanford. (1987). Communication Skills for Unusually Impaired Learners. Springfield, IL: Charles C. Thomas.

[10]. Shalini a/p Sanmargaraja \& Seow Ta Wee. (2008). Kajian Penyediaan Fasiliti Orang Kurang Upaya (OKU) di Institusi Kerajaan di Nusajaya, Johor Bahru: UTHM.

[11]. S.J, Spungin. (1989). Braille literacy: Issues for Blind Persons, Families, Professionals and Producers of Braille. New York: American Foundation for the Blind.

[12]. Taymans, J. M., Swanson, H. L., Schwarz, R. L., Gregg, N., Hock, M. \& Gerber, P. J. (2009). Learning to Achieve: A Review of the Research Literature on Serving Adults with Learning Disabilities. National Institute for Literacy.

[13]. Wong Huey Slew \& Sandiyao Sebestian. (2005). Pendidikan Bagi Komuniti Orang Kurang Upaya Penglihatan diMalaysia: Satu Analisis daripada Perspektif Sejarah. University Malaya Issues in Education, Volume 25.

[14]. Wood, J.W. (2002). Adapting Instruction to Accommodate Students in Inclusive Setting. USA: Merrill Prentice Hall. 